\title{
Workers' Participation in Management with Reference to Blue Bharath Exim Pvt.Ltd, Chennai
}

\author{
Nandha Kumar, S.Praveen Kumar
}

\begin{abstract}
This assessment relies upon the data assembled as the appraisal from the workers of Blue Bharath Exim Pvt Ltd, CHENNAI, and range of one month. The central objective of the investigation was to consider the workers' enthusiasm for the administrators with reference to Blue Bharath Exim. Edifying assessment arrangement was used for the examination. Fundamental subjective inspecting system was used in the assessment for picking the testing. The fundamental data was accumulated strategies for study anyway meet. The assistant data was accumulated from association chronicles and locales. 100 people were met through the gathering. The data was analyzed by using appropriate quantifiable instruments like essential rate examination and chi - square test. This assessment is clear research guided for the motivation to know the level of incorporation in the essential authority technique of then work places and the sort of decisions making workers are related with at Blue Bharath Exim. Moreover, it is found that help of workers in association's fundamental initiative procedure in the board at Blue Bharath Exim Pvt Ltd is sufficient or extraordinary. [1],[ 3],[5]
\end{abstract}

Keywords : participation,management,workers

\section{INTRODUCTION}

Workers' participation in the administrators is a central component of mechanical vote based framework. Generally the possibility of workers' participation in the board insinuates backing of non-authoritative specialists in the essential initiative methodology of the affiliation. Workers' collaboration is generally called work intrigue or laborer support in the board. In Germany it is known as co-affirmation while in Yugoslavia it is known as self-organization. The International Labor Organization has been asking part nations to propel the arrangement of workers' participation in the administrators. Workers' participation in the board proposes mental and enthusiastic commitment of workers in the organization of huge business. It is considered as an instrument were workers have a state in the decision. [7],[9], [11]

\section{RESEARCH METHODOLOGY}

Research Methodology is the strategy used to assemble information and data to choose. The methodology may consolidate creation ask about, meetings, outlines and other research techniques and could fuse both present and undeniable information.

Research Methodology is the exact, speculative examination of the methodologies associated with a field of study. It includes the theoretical examination of the arrangement of procedures and models related with a piece of data. [2 ], [ 4],[6]

\section{OBJECTIVES}

A. Primary Objectives

- The focal goal of the examination is to consider the laborers' investment in the executives basic leadership process at Blue Bharath Exim Pvt Ltd.

B. Secondary Objectives

- To find out laborers level of contribution in the basic leadership procedure of then work places.

- To know the kind of choices making laborers are engaged with.

- To know whether the laborers' suppositions are utilized subsequent to being gathered.

- To realize whether the participative administration brings about productivity or not.

- To know laborers' support in the executives basic leadership procedure improves connection among chiefs and laborers.

- To propose proposals to defeat the experienced omissions.

\section{RESEARCH DESIGN}

An assessment arrangement is the game-plan of conditions for social event and examination of data in way that expects to merge significance to the investigation reason with economy by methodology, the assessment, structure focal points the strategies for data gathering,

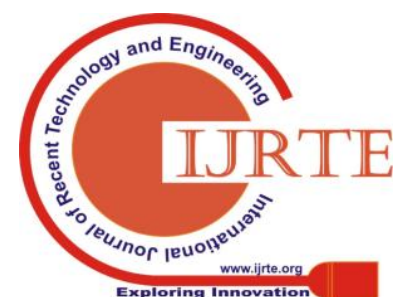


testing plan data examination and comprehension. The assessment has taken the expressive research. Obvious research means depicting the state of nature of convictions as it at present time.

A. Research area:

The area of study covers Blue Bharath Exim Pvt Ltd, Chennai.

B. Research unit:

BLUE BHARATH EXIM PVT., LTD employees.

C. Research period:

Three months.

D. METHOD OF DATA COLLECTION

Data source

- Primary data

- Secondary

E. Primary data

The Primary data was collected from the respondents by administering a structured questionnaire and also through observation, interviews, discussion with manager and the workers.

F. Secondary data

The secondary data has been collected through text book, records of Blue Bharath Exim Pvt Ltd, journal, academic reports and Internet is used for the study.

G. Research instrument:

Questionnaire consists of open ended, dichotomous, and closed ended.

H. Sample population:

Sample population is 130 employees.

I. Sample size:

The sample size is taken as 100 .

J. Sampling Technique:

The sampling technique used is random sampling.

\section{K. STATISTICAL TOOLS USED}

Statistical tools

1. Percentage Analysis.

2. Chi - square

Table: 1 Type of Decision Making

\begin{tabular}{|l|l|l|l|}
\hline S.NO & Type of Decision Making & No. of respondents & $\begin{array}{l}\text { Percentage } \\
\text { respondents }\end{array}$ \\
\hline 1 & Important decisions & 54 & $54 \%$ \\
\hline 2 & Some decisions & 37 & $37 \%$ \\
\hline 3 & Very few decisions & 9 & $9 \%$ \\
\hline & Total & 100 & $100 \%$ \\
\hline
\end{tabular}

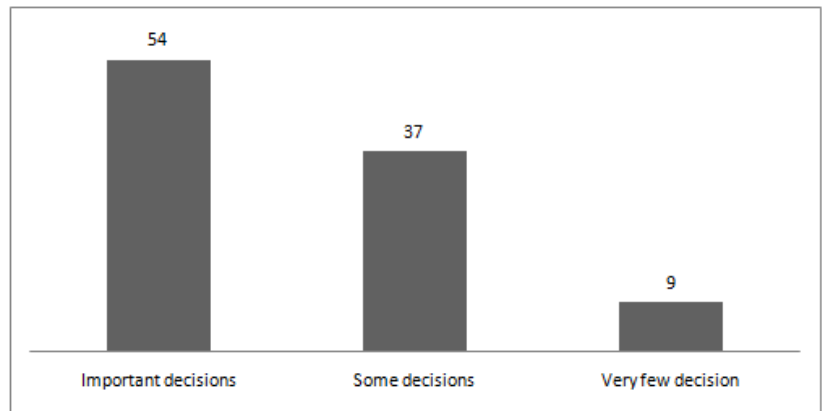

Fig:1 Type of Decision Making

Table: 2 Decision Of Workers Which Are Implemented.

\begin{tabular}{|l|l|l|l|}
\hline S.N0 & Type of Decision Making & No. of respondents & $\begin{array}{l}\text { Percentage } \\
\text { respondents }\end{array}$ \\
\hline 1 & Important decisions & 61 & $61 \%$ \\
\hline 2 & Some decisions & 25 & $25 \%$ \\
\hline 3 & Very few decisions & 14 & $14 \%$ \\
\hline & Total & 100 & $100 \%$ \\
\hline
\end{tabular}

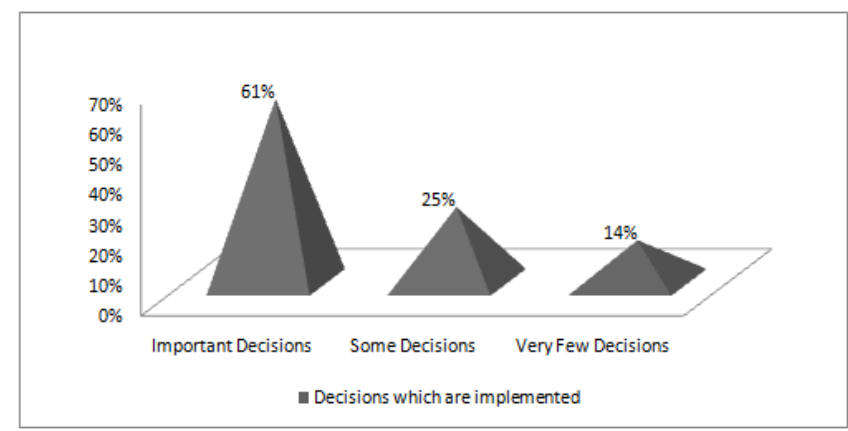

Fig: 2 Decision Of Workers Which Are Implemented

TABLE: 3 FORMS OF WORKERS' PARTICIPATION

\begin{tabular}{|l|l|l|l|}
\hline S.NO & Forms & No. of respondents & $\begin{array}{l}\text { Percentage } \\
\text { respondents }\end{array}$ \\
\hline 1 & Suggestion boxes & 10 & $10 \%$ \\
\hline 2 & Individual participation & 59 & $59 \%$ \\
\hline 3 & Representatives & 31 & $31 \%$ \\
\hline & Total & 100 & $100 \%$ \\
\hline
\end{tabular}




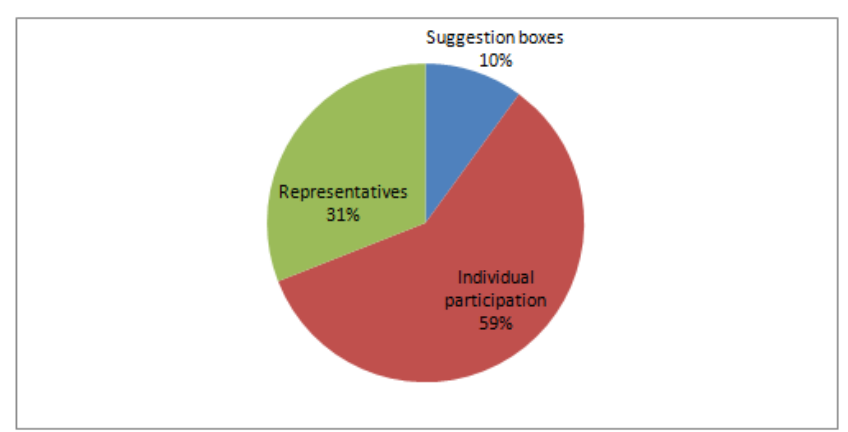

Fig:3 FORMS OF WORKERS' PARTICIPATION

Table :4 Participation Of Workers Relating To Policy Decisions

\begin{tabular}{|l|l|l|l|}
\hline S.NO & Policy Decisions & No. of respondents & $\begin{array}{l}\text { Percentage } \\
\text { respondents }\end{array}$ \\
\hline 1 & Every time & 14 & $14 \%$ \\
\hline 2 & Some time & 69 & $69 \%$ \\
\hline 3 & Few time & 17 & $17 \%$ \\
\hline & Total & 100 & $100 \%$ \\
\hline
\end{tabular}

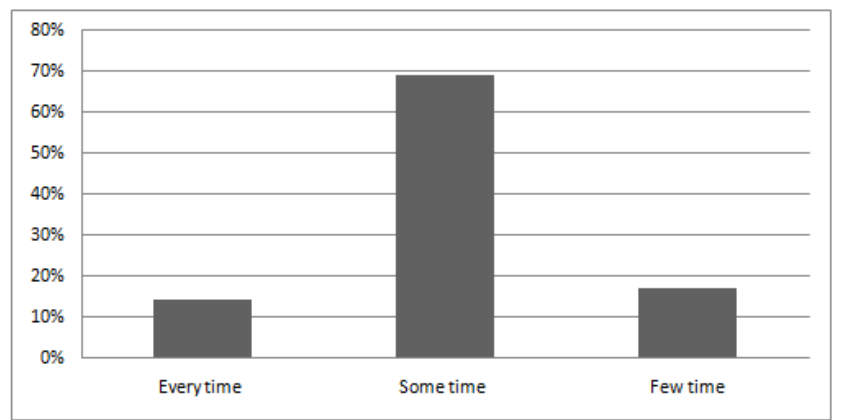

Fig:4 Participation Of Workers Relating To Policy

Decisions.

\section{CHI - SQUARE TEST - NO: 1}

Aim:

To find significant relationship between the age and the freedom of expression during decision making process. [8],[ 10], [12]

\section{Null Hypothesis (HO):}

There is no significant relationship between the age and the freedom of expression during decision making process.

Alternative Hypothesis (H1):

There is a significant relationship between the age and the freedom of expression during decision making process.

\section{Table:5}

\begin{tabular}{|l|l|l|l|l|l|l|}
\hline Age & $18-25$ & $26-30$ & $31-35$ & $36-40$ & Above 41 & Total \\
\cline { 1 - 6 } Freedom & & & & & & \\
\cline { 1 - 5 } Freely and & 0 & 1 & 9 & 8 & 10 & 28 \\
\hline To a Great & 5 & 4 & 5 & 6 & 6 & 26 \\
\hline To some & 6 & 5 & 6 & 7 & 8 & 32 \\
\hline Very little & 4 & 2 & 3 & 1 & 1 & 11 \\
\hline Not at all & 1 & 1 & 1 & 0 & 0 & 3 \\
\hline Total & 16 & 13 & 24 & 22 & 25 & 100 \\
\hline
\end{tabular}

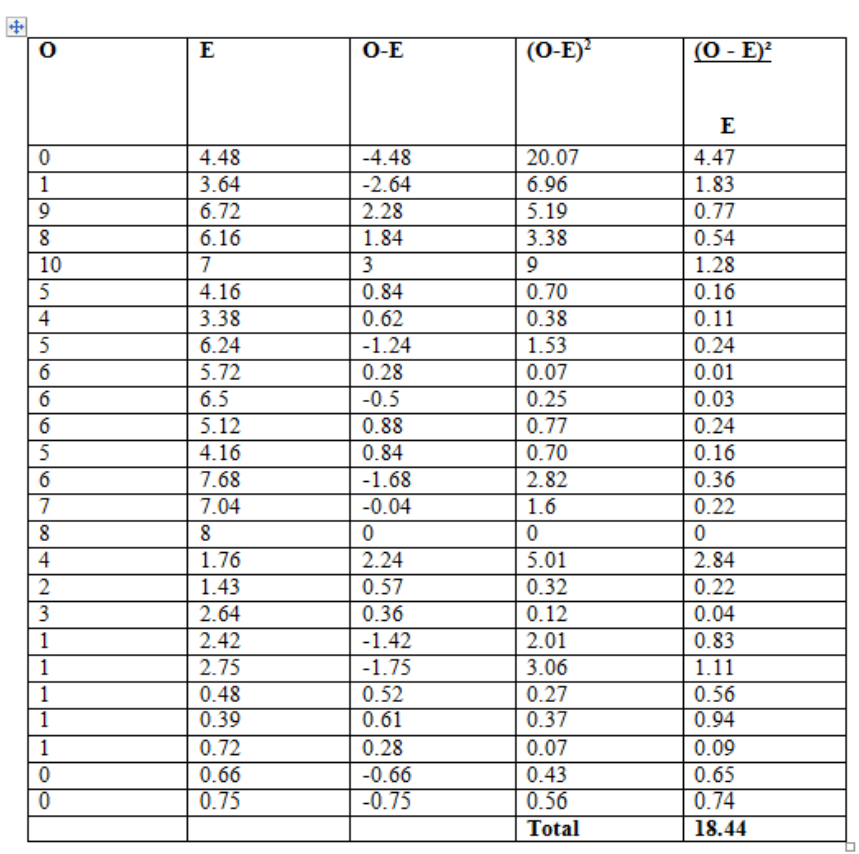

\section{V.RESULTS}

Majority of the respondents state that the gatherings are organized once in a month and few state that gatherings are orchestrated quarterly.

Most of the respondents have just partaken sometimes in the administration basic leadership gatherings.

Majority of the respondents state that when there is a significant choice to be taken then they are welcomed by the administration.

In the administration basic leadership gatherings significant choices proposed by the organization laborers are constantly acknowledged.

When there is a significant choice to be taken individual investment is constantly supported and some time laborers delegates alone welcome to the gatherings and the board likewise utilize proposal boxes to know the laborers' recommendation.

Majority of the respondents state that lone some time the laborers are welcomed when there is choice identified with arrangement. [13], [15] ,[ 17] 
Most of the respondents state that when there is choices with respect to working and administration conditions then specialists have been welcomed. [14],[16], [18]

When there is choice identified with organization and supervisions just some time the laborers are welcomed.

Majority of the respondents state that laborers can express their feelings unreservedly and straightforwardly somewhat.

Most of the respondents state that more often than not all workers are called to the basic leadership procedure and some time just the first line managers are required the gatherings.

During basic leadership process however much of the time there emerges distinction of supposition among the individuals still lion's share of respondents state this does not happens consistently.

It was likewise uncovered that when laborers' assessments are fused into choices, there is progressively invigorated of thoughts and more noteworthy exertion and co-activity. It likewise raises the resolve of the laborers, understand having a place and the mentally associated with the running of the organization, they will regularly react to imparted issues to develop recommendations and strange endeavors.

Majority of the laborers' opposite that laborers' support in the executives improves understanding among supervisors and laborers. [25],[27],[29]

\section{DISCUSSION}

Workers ought to be consistently spurred to give their support in the executives and the executives ought to likewise advance specialists interest in the board with legitimate energy. [26],[28],[30]

- Management should put more exertion in urging their laborers to concoct recommendations and valuable choices and try to fuse them into the organization's choices on strategy and organization.

- Management should expand the recurrence and level of specialist investment in basic leadership considering the way that they are the individuals doing the primary employable work as they are in the better position to recognize what goes on those territories. [31],[33],[32]

- Considering the significance and advantages of participative administration particularly in the development and soundness of organization, time and cash venture on it ought to be made appropriately and shrewdly to stay away from second thoughts.

- In request to stay away from distinction of feelings the principle target of any plan for investment ought to be explicit and definite that care to empower laborers perceive the regions their proposals and assessments are generally required

\section{CONCLUSION}

Laborers Participation in Management has expected incredible significance nowadays since it lessens modern agitation and aides in scattering employees ${ }^{\text {ee }}$ misjudging about the standpoint of the executives in industry. Laborers investment has been found to effectsly affect representative disposition, duty and gainfulness even additionally on the productivity of the administration. Accordingly participative administration ought to be viewed as an unavoidable instrument in any association. [19],[21],[23]

The administration and specialist have equivalent interests in the survival and the thriving of the business. Laborers' interest in the executives incorporates work the board co-activity, co-appointment, co-organization, joint conference, joint basic leadership, and so forth the genuine cooperation is sharing the power in choice making.Participation of laborers in organization's basic leadership process in the executives at Blue Bharath Exim Pvt Ltd is adequate or great. It is additionally useful to make tranquil and agreeable condition in the organization and furthermore helps in expanding the benefit in the organization and furthermore the laborers support in the board improves understanding among directors and laborers. [20],[22], [24]

\section{REFERENCES}

1. G BharthVajan R., Ramachandran S.,Psychographic dimensions of training,2016,International Journal of Pharmacy and Technology,V-8,I-4,P-23727-23729

2. Balakrishnan P., Bharthvajan R.,A study on human resource planning in hospitals in Chennai City,2014,International Journal of Applied Engineering Research,V-9,I-22,P-7503-7507

3. Priyadarsini P., Bharthvajan R.,Role of emotional intelligence training programme in reducing the stress of the nurses,2014,International Journal of Applied Engineering Research,V-9,I-22,P-7411-7421

4. Kerinab Beenu G., Bharthvajan R.,Empirical analysis on the cosmetic buying behavior of young women in South India,2014,International Journal of Applied Engineering Research,V-9,I-22,P-7361-7366

5. Balakrishnan P., Bharthvajan R.,Whistling in the wind,2014,International Journal of Applied Engineering Research,V-9,I-22,P-7586-7593

6. Krishnan B., Peter M.,Health hazards of Indian Bpo employee-an alarming issue,2014,International Journal of Applied Engineering Research,V-9,I-22,P-7336-7341

7. Kerinab Beenu G.H., Peter M.,Role of insurance in economic development,2014,International Journal of Applied Engineering Research,V-9,I-22,P-7532-7539

8. Balakrishnan P., Peter M., Priyadarsini P.,Efficiency of safety measures for wellbeing of employees in manufacturing industry,2014,International Journal of Applied Engineering Research,V-9,I-22,P-7376-7382

9. Anbarasi M., Praveen Kumar S.,Online sales promotions of herbal products and its effectiveness towards tanisha.com,2019,Indian Journal of Public Health Research and Development,V-10,I-1,P-195-200

10. Anbarasi M., Praveen Kumar S.,Various online marketing and promotions strategies to improve the validation towards the organic products in the pharmaceutical sectors,2019,Indian Journal of Public Health Research and Development,V-10,I-1,P-263-269

11. Loganathan R., Praveen Kumar S.,Grievance handling a key factor for solving issues of employees in an organization,2014,International Journal of Applied Engineering Research,V-9,I-22,P-7483-7491

12. Loganathan R., Praveen Kumar S.,Study on preference of private label brands in super and Hypermarkets, 2014,International Journal of Applied Engineering Research,V-9,I-22,P-7327-7335

13. Smitha M., Praveen Kumar S.,Understanding stress and its managementamong the nurses in Chennai city,2014,International Journal of Applied Engineering Research,V-9,I-22,P-7560-7565 
14. Kerinab Beenu G.H., Praveen Kumar S.,A study on the investment behavior of Chennai investors in mutual fund schemes,2014,International Journal of Applied Engineering Research,V-9,I-22,P-7520-7525

15. Loganathan R., Praveen Kumar S.,Retention strategies key for organizational productivity,2014,International Journal of Applied Engineering Research,V-9,I-22,P-7443-7447

16. Pavithra J., Ganesan M., Brindha G.,State wise analysis of microfinance sector in India,2016,International Journal of Pharmacy and Technology,V-8,I-4,P-23417-23432

17. Pavithra J., Ganesan M.,A comparative study on microfinance in India and abroad,2016,International Journal of Applied Business and Economic Research,V-14,I-8,P-5471-5476

18. Pavithra J., Ganesan M.,A study on awareness and impact of micro-financial schemes,2016,International Journal of Applied Business and Economic Research,V-14,I-8,P-5449-5460

19. Senthilmurugan P., Pavithra J.,Consumer preference towards organised retailing with reference to Big Bazaar,2014,International Journal of Applied Engineering Research,V-9,I-22,P-7469-7475

20. Senthilmurugan P., Pavithra J.,Implication of social media marketing in growing healthcare industry,2014,International Journal of Applied Engineering Research,V-9,I-22,P-7448-7456

21. Loganathan R., Pavithra J.,Consumer perception towards private label brand over other brands in super markets and hypermarkets,2014,International Journal of Applied Engineering Research,V-9,I-22,P-7355-7360

22. Kerinab Beenu G., Pavithra J.,Tradeâ€"off between liquidity and profitability in logistics industry,2014,International Journal of Applied Engineering Research,V-9,I-22,P-7398-7401

23. Kerinab Beenu G., Pavithra J.,A study on the prospective consumerâ€ $€^{\mathbf{T M}_{\mathrm{S}}}$ perception towards utility cars in Chennai city,2014,International Journal of Applied Engineering Research,V-9,I-22,P-7526-7531

24. Pavithra J., Dilli Babu P., Ambuli T.V.,A study on budgetary control at Maruti Service Masters, Chennai,2014,International Journal of Applied Business and Economic Research,V-12,I-2,P-151-161

25. Pavithra J., Dilli Babu P., Ambuli T.V.,A study on customer satisfaction of retro Garments Pvt Ltd, Chennai,2014,International Journal of Applied Business and Economic Research,V-12,I-2,P-381-391

26. Kerinab Beenu G.H., Pavithra J., Senthilmurugan P.,A study on the influence of promotional activities for TATA ARIA among consumers in Chennai,2014,International Journal of Applied Engineering Research,V-9,I-22,P-7572-7578

27. Vijayaragavan S.P.,An investigative expert that's general FBG sensors, International Journal of Mechanical Engineering and Technology,V-8,I-8,PP-1500-1505,Y-2017

28. Vijayaragavan S.P.,Equalization routing protocol for Wi-Fi sensor strategy,International Journal of Mechanical Engineering and Technology,V-8,I-8,PP-1662-1666,Y-2017

29. Karthik B., Kiran Kumar T.V.U., Vijayaragavan P., Bharath Kumaran E.,Design of a digital PLL using 0.35 $\hat{\mathrm{I}}^{1 / 4 \mathrm{~m}}$ CMOS technology,Middle East Journal of Scientific Research,V-18,I-12,PP-1803-1806,Y-2013

30. Kanniga E., Selvaramarathnam K., Sundararajan M.,Kandigital bike operating system,Middle - East Journal of Scientific Research,V

31. Jasmin M., Vigneshwaran T., Beulah Hemalatha S.,Design of power aware on chip embedded memory based FSM encoding in FPGA,International Journal of Applied Engineering Research,V-10,I-2,PP-4487-4496,Y-2015

32. Jasmin M.,Optimization techniques for low power VLSI circuits,Middle East Journal of Scientific Research,V-20,I-9,PP-1082-1087,Y-2014

33. Jasmin M., Vigneswaran T.,Fuzzy controller for error control of on - Chip communication,2017 International Conference on Algorithms, Methodology, Models and Applications in Emerging Technologies, ICAMMAET 2017,V-2017-January,I-,PP-1-5,Y-2017

\section{AUTHORS PROFILE}

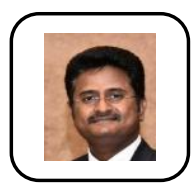

Nandha Kumar Research Scholar ,Department of MBA, Bharath Institute of Higher Education and Research, Tamilnadu, India

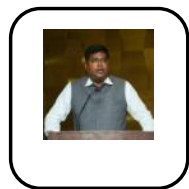

Dr. S.Praveen Kumar Assistant Professor ,Department of MBA, Bharath Institute of Higher Education and Research, Tamilnadu, India 